\title{
INVESTIGATION OF THE INFLUENCE OF UHF ELECTROMAGNETIC FIELD ON THE OUTPUT OF ROLLED GROATS OF WHEAT SPELT
}

\author{
Nina Osokina ${ }^{1}$ \\ ninaosokina1953@gmail.com \\ Vitalii Liubych ${ }^{1}$ \\ LyubichV@gmail.com \\ Volodymyr Novikov ${ }^{T}$ \\ 1990vovanovikov1990@gmail.com \\ Ivan Leshchenko ${ }^{1}$ \\ kondorkomik@gmail.com \\ Vasyl Petrenko \\ Laboratory of Grain Milling and Bakery Technology \\ Institute of Food Resources of National Academy of Agrarian Sciences of Ukraine \\ 4-A Yevhen Sverstiuk str., Kyiv, Ukraine, 03041 \\ vasylpetrenko07@gmail.com \\ Svitlana Khomenko \\ Spring Wheat Breeding Laboratory \\ The V. M. Remeslo Myronivka Institute of Wheat National Academy of Agrarian Sciences of Ukraine \\ 68 Tsentralna str., Myronivskyi dist., Kyiv reg., Ukraine, 08853 \\ homenko.mip@ukr.net \\ Viktor Zorunko \\ Department of Plant Protection, Genetics and Breeding \\ Odessa State Agricultural Experiment Station National Academy of Agrarian Sciences \\ 24 Mayak road., smt. Khlebodar, Belyaevsky distr., Odessa reg., Ukraine, 67667 \\ zorunko1@gmail.com \\ Oleksandr Balabak \\ Department of Genetics, Selection and Reproductive Biology of Plants \\ The National Dendrological Park "Sofiyivka" of the National Academy of Sciences of Ukraine \\ 12A Kievskaya str., Uman, Ukraine, 20300 \\ o.a.balabak@ukr.net \\ Valentyn Moskalets ${ }^{2}$ \\ moskalets7819@i.ua \\ Tatiana Moskalets ${ }^{2}$ \\ shunyascience@ukr.net
${ }^{1}$ Department of Technology of Storage and Processing of Grain
Uman National University of Horticulture
1 Instytutska str., Uman, Ukraine, 20305
${ }^{2}$ Selection and Technological Department \\ Institute of Horticulture of the National Academy of Agrarian Sciences \\ 23 Sadova str., Novosilky, Ukraine, 03027
}

Abstract

Wheat spelt is a promising crop. A high food value and high-quality biochemical composition of grains make wheat spelt favorably remarkable for groats production. Preservation of the food value is an important task of food production, but regimes of 
grain processing must provide good culinary quality and consumption safety.

The aim of our work is to study regimes of irradiation and humidification of wheat spelt grains, influencing the output and culinary quality of the ready product; development of recommendations as to production of rolled groats.

There is studied an influence of different regimes of water-thermal processing on the total output of groats and rolled groats of the highest sort. The reliable connection between the output of rolled groats of the higher sort and duration of irradiation by the electromagnetic field of the ultrahigh frequency and grain humidification has been established. No essential connection as been established between humidification and the total output of groats.

The duration increase of UHF-irradiation (>120-140 s) conditions the essential growth of dust middlings and decrease of rolled groats of the highest sort. The long-term irradiation (180 s) conditions the decrease of groats boiling duration by $17 \%$ comparing with the short-term processing (20 s).

The established influences of the factors are preconditions for transferring obtained technological solutions and their use under conditions of existing groats factories of different productivity.

Keywords: water-thermal processing, microwave irradiation, wheat spelt, groats output, culinary estimation.

DOI: $10.21303 / 2504-5695.2020 .001533$

\section{Introduction}

Groats are traditional food products together with bakery products. The popularity increase of groats products in the last decade is caused by popularization of health nutrition.

Wheat spelt or two-grain wheat (Triticum dicoccum Shrank.) is a type of membranous wheat. Plants of this variety are characterized with resistance to unfavorable climatic conditions, tolerance to many fungal diseases, simplicity to soils. Today wheat spelt is widely introduced in organic agriculture [1-3].

Many scientists [4-7] note the superiority of wheat spelt grains by food value comparing with soft wheat. The biochemical composition of wheat spelt grains is in the wide spectrum. The content of determining components is within: protein 12.7-25.7\%; starch 50.0-66.2\%; lipids 0.9-4.9\%; cellulose 1.0-2.2\% [8-11]. Wheat spelt contains more lutein that may be important for preventing vision disorders [12]. Wheat spelt grains contain more iron, selenium, zinc, manganese and copper comparing with soft wheat [7].

Groats and flour are produced of wheat spelt in food industry. Products of spelt grains processing have a high culinary quality. Spelt grains have perfect dietetic properties. As a result of slower assimilation of starch, wheat spelt has a low glycemic index [7, 13]. It also contains less allergic substances than soft wheat and spelt.

The stable growth of production volumes of wheat spelt grains, especially in the developed countries of Europe and Southern America is observed. There appears a necessity to search for rational ways of its production. But as a result of low information about groats and flour-grinding properties of wheat spelt grains, processing manufactures are unable to use the potential of this crop effectively.

The use of irradiation of the ultrafrequent electromagnetic field (UHF EMF) is a wellknown method for intensifying grain processing technologies. At that it is almost not used for wheat grain processing, and the studying level of this question is insufficient.

Determination of regularities of an influence of different regimes of wheat spelt grain water-thermal processing allows to foresee technical parameters of groats production. At the same time it is necessary to determine an influence on culinary properties. So, correspondent scientific studies are urgent.

\section{Analysis of problem condition}

Wheat spelt gains popularity in food production. Obtained bakery products have a yellow tint, and somewhat nut smell. Flour of wheat spelt grains is mainly fit for products with unessential needs in gluten: biscuit, pastry, waffle products, fruitcakes. But studies about wheat spelt grain use for groats production are absent.

Wheat spelt grains are similar to soft wheat ones, widely used in agriculture today, by anatomic form. Peripheral parts of wheat spelt grains are presented by seed and fruit capsules. Fruit 
capsules consist of the longitudinal, transversal and tubular layers. The aleurone layer of wheat spelt is presented by thick-walled cells of different form and size [15]. Despite the similarity of the anatomic construction of wheat spelt grains to ones of soft wheat, spelt characterizes with the even placement of important nutrients in capsules and endosperm [16, 17]. But it essentially differs by physical-chemical properties. Work [18] proves that wheat spelt has higher heat-creating capacity comparing with soft wheat and barley, and it is recommended to use it as a renewing energy source in regions of its production.

Wheat spelt grain processing in groats products is a promising direction. It has been established, that wheat spelt grains are used for producing whole and comminuted groats. Porridge of groats has a higher biological value and culinary properties, pleasant taste and smell, good outlook, fine friableness. These studies deal with whole and comminuted groats. At the same time the culinary quality formation depending on processing technology elements is insufficiently studied.

Due to the abrupt growth of a share of refined products in human nutrition, the content of dietary fibers decreased. The use of whole-grain products is the most available and cheap source of dietary fibers. Shortcomings of whole-grain products are a low culinary quality as a result of the hard consistence at chewing [14]. It has been established, that porridges of wheat spelt don't cause essential uncomfortable sensations at chewing [19]. It makes production of whole-grain groats from wheat spelt promising.

It has been established, that an output and quality of groats are essentially influenced by different regimes of water-thermal processing and peeling of grains [14, 20]. Water-thermal processing includes only humidification of grains or combination of humidification with heating (steaming). The traditional technological operation with grains is its peeling for improving a culinary mark and cleaning of a grain.

One of grain thermal processing methods is used at rolled groats production. Grain steaming is most widespread. New methods are infrared irradiation and one by the electromagnetic field of ultrahigh frequency (UHF-irradiation). Their use shortens, simplifies the technological scheme and decreases the grain processing duration.

Today there are many attempts to introduce UHF-irradiation as a method of grain thermal processing. Microwaves have no ionizing character. UHF-irradiation just doesn't influence the chemical composition. A motive factor of processes in grains is heat. The electromagnetic field causes vibrations of bound electric charges (dipoles) in grains. It creates dielectric heating in places of water and lipids. At that the "boiling" process takes place in a grain. Different physical-chemical processes, connected with protein and starch, go. Dextrinization of starch and decay of lipid links take place. As a result, technological properties change [21-23]. At that the ready product assimilability increases, the food value and the content of water-soluble substances grow, the term of groats cooking shortens. An important result of irradiation in a microwave oven is sterilization.

The use of UHF-irradiation at producing groats is elucidated very little in literary sources. UHF-irradiation is most often used for producing "torn" groats of corn and buckwheat grains. Its influence on the output and quality of rolled groats of wheat (spelt) grains is not studied at all. Most researches deal with rheological and technological properties of flour of irradiated grains. Several works are devoted to consumption safety and changes of the biochemical composition. These properties don't describe the influence on the output and quality of rolled groats.

Works that studied the question of using UHF-irradiation of cereal grains don't propose an effective way of using it at rolled groats production. Today there are no recommendations as to wheat spelt grain processing. Mechanisms of changes in the groats output and quality depending on irradiation duration and humidification of grains need fixation that is an interesting question from the theoretical point of view. It makes preconditions for transferring obtained theoretical solutions.

The aim of the work was to establish optimal regimes of wheat spelt grain irradiation and humidification by the output and culinary quality of the ready product. It gives a possibility to produce rolled groats with the high culinary quality of wheat spelt. Quality parameters of groats will correspond to requirements of SSU 1055:2006. «Fast-boiled groats. Technical conditions». 
The following tasks were set for attaining this aim:

- to establish the influence of the UHF-irradiation and humidification duration of wheat spelt grains on the rolled groats output;

- to offer a classification of obtained groats after grain rolling;

- to study the culinary quality of groats depending on production regimes;

- to substantiate rational regimes for processing wheat spelt grain in groats.

\section{Materials and methods}

\section{1. Raw material}

The research object was wheat spelt grains of line LP1152 (obtained by hybridization of Triticum dicoccum (Schrank) Schuebl./Triticum durum Desf.).

\section{2. Equipment for research}

Grains were peeled using air and sieve separators (Fig. 1).

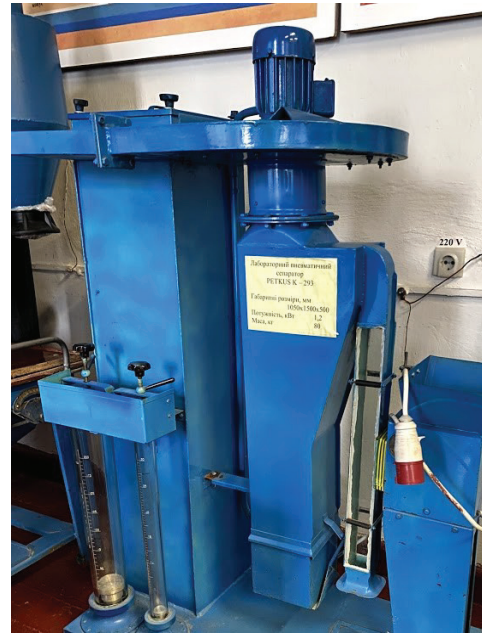

$a$

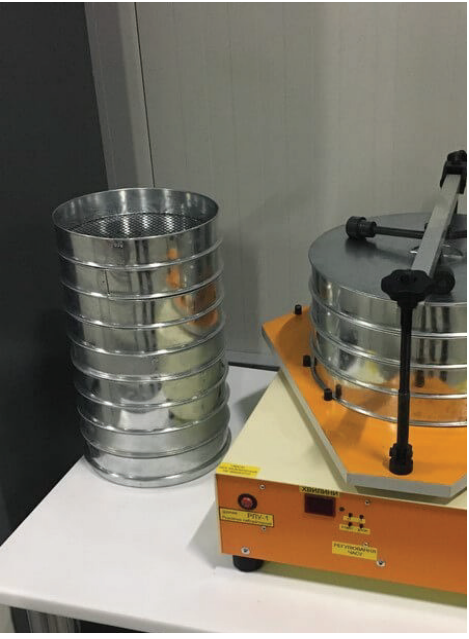

$b$

Fig. 1. Equipment for grain cleaning: $a$ - air separator PETKUS K-293; $b$ - sieve SLU-1

Humidification was conducted using a microdrop sprinkler. Grain irradiation by the electromagnetic field of ultrahigh frequency was conducted in the microwave oven: RAINFORD RMW-301 DGC/S, nominal power $1000 \mathrm{~W}$, microwave frequency $2450 \mathrm{MHz}$ (Fig. 2).

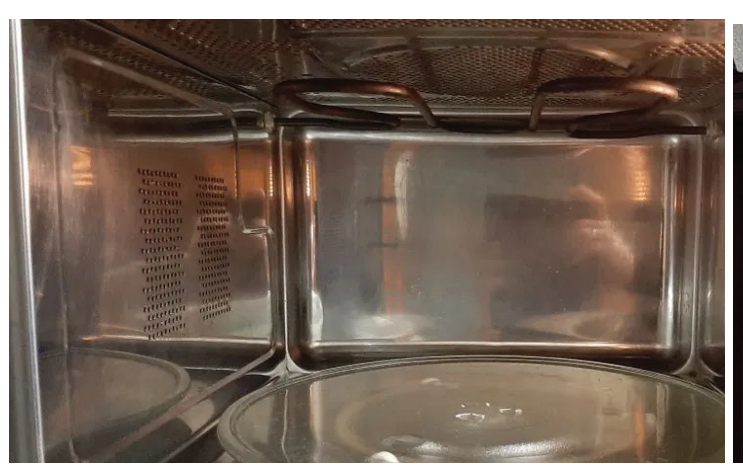

$a$

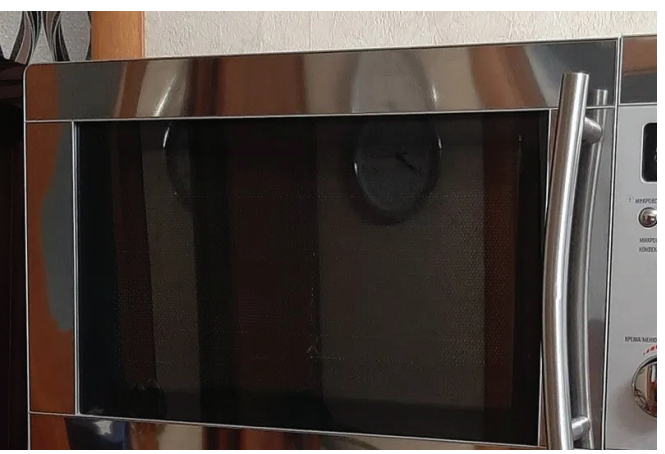

$b$

Fig. 2. Microwave oven RAINFORD RMW-301 DGC/S: $a$ - chamber for research; $b$ - device outlook

Grains were rolled by the rolling press RPK-200 with cut rollers (Fig. 3). 


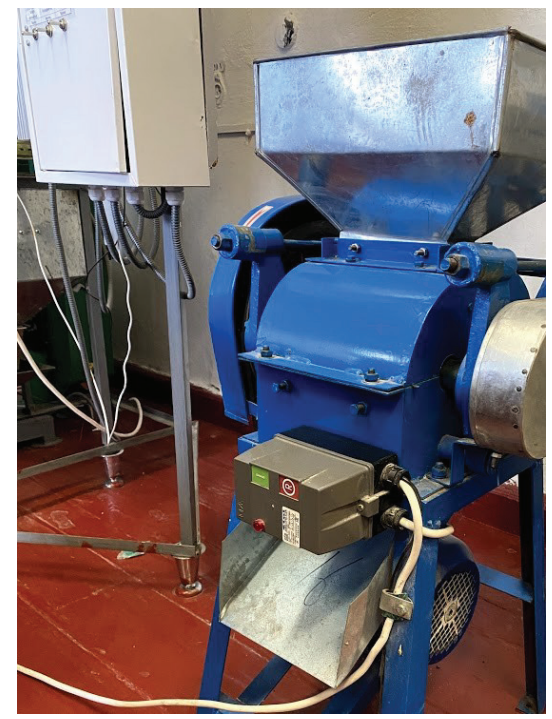

Fig. 3. Rolling press RPK-200

Its rotation frequency was $450 \mathrm{rot} / \mathrm{min}$. Peeling products were fractioned on the laboratory sieve SLU-1.

\section{3. Statistical processing of experimental data}

The studies were conducted in three iterations, randomized in time. The results of the analytic iterations were processed using programs Microsoft Ecxel 2010 and STATISTICA 12. The experiment quality was estimated by the cogency of variation coefficient of samples, formed of the analytic iterations' data. The experiment was considered reliable at their inessential variation. Dependencies between the factors were determined by the methods of dispersion and regression analysis. The factors' influence degree was established according to Partial eta-squared $\left(\Pi^{2}\right)$.

\section{Experiments}

\section{1. Base parameters of grain quality}

Wheat spelt grains, stored under identical conditions were used for the experiment. Their humidity was stable as $12.0 \pm 0.3 \%$. The mass of a sample for the analysis was $100 \mathrm{~g}$.

\section{2. Characteristic of the production model of groats under laboratory conditions}

The process of producing rolled groats of wheat grains was modeled under laboratory conditions (Table 1) according to "Rules of organization and conduction of the technological process at a groats factory" [24].

Table 1

Characteristic of technological operations of groats production under laboratory conditions

\begin{tabular}{|c|c|c|}
\hline Technological operation & Equipment & Note \\
\hline & Laboratory air separator PETKUS K-293 & Air flow speed $-6 \mathrm{~m} / \mathrm{s}$ \\
\hline Preliminary grains peeling & Laboratory sieve SLU -1 & $\begin{array}{l}\text { Elimination of admixtures, obtained by sieve orifice } \\
\varnothing 10 \mathrm{~mm} \text { and sieve pass } 1,7 \times 20 \mathrm{~mm}\end{array}$ \\
\hline Water-thermal heating & $\begin{array}{c}\text { Microdrop sprinkler } \\
\text { Grain irradiator RAINFORD RMW-301 } \\
\text { DGC/S }\end{array}$ & $\begin{array}{l}\text { Grain humidification by, } \%: 0.5 ; 1.0 \\
\text { Irradiation duration, s: } 20 ; 40 ; 60 ; 80 ; 100 ; 120 ; 140 \text {; } \\
160 ; 180 \\
400 \times 200\end{array}$ \\
\hline Grain rolling & Rolling press RPK-200 & $\begin{array}{l}\mathrm{HS} / \mathrm{FS} \\
1: 1\end{array}$ \\
\hline $\begin{array}{l}\text { Separation of rolling } \\
\text { products }\end{array}$ & Laboratory sieve SLU -1 . & $\begin{array}{l}\text { Elimination of admixtures, obtained by sieve orifice } \\
\qquad 6.5 \mathrm{~mm} \text { and sieve pass No. } 067\end{array}$ \\
\hline
\end{tabular}




\begin{abstract}
4. 3. Peculiarities of the experimental study of innovation methods of water-thermal processing

Water-thermal processing (WTP) of grains included humidification and irradiation in a microwave oven (UHF-oven). Humidification was conducted in hermetic cylinders during 30 min.

A sample for the analysis was evenly distributed by the whole working surface of the microwave oven. Grains were rolled without their cooling. A distance between rollers of the rolling press was $1 \mathrm{~mm}$. Rolling products were cooled at the room temperature to $15^{\circ} \mathrm{C}$. 5 fractions of groats were obtained at groats products separation. Their detail characteristic is presented in Table $\mathbf{2}$. The output of rolled groats and other fractions is presented in percents $(\% \pm 0.1)$.
\end{abstract}

Table 2

Characteristic of different fractions of rolled groats

\begin{tabular}{cc}
\hline Groats fractions & Storage conditions \\
\hline grains stuck together & Sieve orifice $6.5 \mathrm{~mm}$ \\
rolled groats of the highest sort & Sieve pass $6.5 \mathrm{~mm}$ \\
rolled groats of the first sort & sieve orifice $3.2 \mathrm{~mm}$ \\
& Sieve pass $3.2 \mathrm{~mm}$ \\
(groats) morsel & sieve orifice $2.0 \mathrm{~mm}$ \\
Dust middlings & Sieve pass 2.0 \\
\end{tabular}

The culinary estimation was conducted according to the patent No. 104152 "Method of culinary estimation of groats products of triticale and wheat grains".

\title{
5. Results
}

The output samples data of all fractions of groats and dust middlings, obtained without and after humidification at different durations of processing in the microwave oven are collected in Table 3.

Table 3

Variation changeability of the rolled groats output after humidification and without it

\begin{tabular}{|c|c|c|c|c|c|}
\hline \multirow{2}{*}{$\begin{array}{l}\text { Statistical process- } \\
\text { ing parameter }\end{array}$} & \multicolumn{3}{|c|}{ Groats output, \% } & \multirow{2}{*}{$\begin{array}{c}\text { Total groats } \\
\text { output, } \%\end{array}$} & \multirow{2}{*}{$\begin{array}{l}\text { Dust mid- } \\
\text { dlings, \% }\end{array}$} \\
\hline & Groats of the highest sort & Groats of the first sort & Morsel & & \\
\hline Mean & $62.7^{a} / 73.5^{b}$ & $24.3^{a} / 17^{b}$ & $8.6^{a} / 4.4^{b}$ & $95.5^{a} / 94.8^{b}$ & $4.5^{a} / 5.2^{b}$ \\
\hline Median & $69.9^{a} / 79.9^{b}$ & $20.2^{a} / 13.8^{b}$ & $6.4^{a} / 2.8^{b}$ & $96.7^{a} / 96.5^{b}$ & $3.3^{a} / 3.6^{b}$ \\
\hline Minimum & $12.5^{a} / 28.9^{b}$ & $8.2^{a} / 4.8^{b}$ & $2.4^{a} / 1.3^{b}$ & $92.4^{a} / 88.6^{b}$ & $2.6^{a} / 2.3^{b}$ \\
\hline Maximum & $85.3^{a} / 89.7^{b}$ & $58.2^{a} / 46.3^{b}$ & $26.0^{a} / 22.1^{b}$ & $97.4^{a} / 97.7^{b}$ & $7.6^{a} / 11.4^{b}$ \\
\hline Standard Error & $22.4^{a} / 15.4^{b}$ & $15.5^{a} / 11.5^{b}$ & $6.9^{a} / 4.9^{b}$ & $1.9^{a} / 2.9^{b}$ & $1.9^{a} / 2.9^{b}$ \\
\hline Coef.Var. & $35.7^{a} / 21.0^{b}$ & $63.7^{a} / 68.0^{b}$ & $80.8^{a} / 111^{b}$ & $1.9^{a} / 3.1^{b}$ & $41.5^{a} / 57.1^{b}$ \\
\hline
\end{tabular}

Note: $a$-indices without humidification; $b$-indices after grain humidification.

The data variation of the samples of the highest sort rolled groats output, obtained after humidification was less comparing with analogous ones, obtained without it. It testifies to less deviation of values of this parameter from the mean number of a sample. But in both cases the data variation was essential, because the variation coefficient was more $10 \%$. It testifies to the essential influence of another factor, namely irradiation duration in a microwave oven. The data variation of the samples of the total groats' output differs by an unessential variation coefficient $(<10)$. That is why the probability of the influence of different regimes of water-thermal processing is rather low.

The output processes of groats products may be described by nonlinear models:

$$
\text { Highest sort }=-5,5159+1,4839 x+46,713 y-0,0063 x^{2}-0,1643 x y-19,0593 y^{2}, \%
$$


where $x$-grain irradiation duration in a microwave oven, $\mathrm{s} ; y$ - humidification gradient, $\%$.

$$
\begin{gathered}
\text { First sort }=72,558-30,8593 x-1,0383 y+18,0963 x^{2}+0,0599 x y+0,0044 y^{2}, \% \\
\text { Morsel }=27,4369-12,3926 x-0,3744 y-0,2963 x^{2}+0,0709 x y+0,0015 y^{2}, \% \\
\text { Dust middlings }=5,5209-3,4611 x-0,0712 y+1,2593 x^{2}+0,0335 x y+0,0005 y^{2}, \%
\end{gathered}
$$

where $x$-humidification gradient, $\% ; y$-grain irradiation duration in a microwave oven, $\mathrm{s}$. These dependences may be presented graphically (Fig. 4).

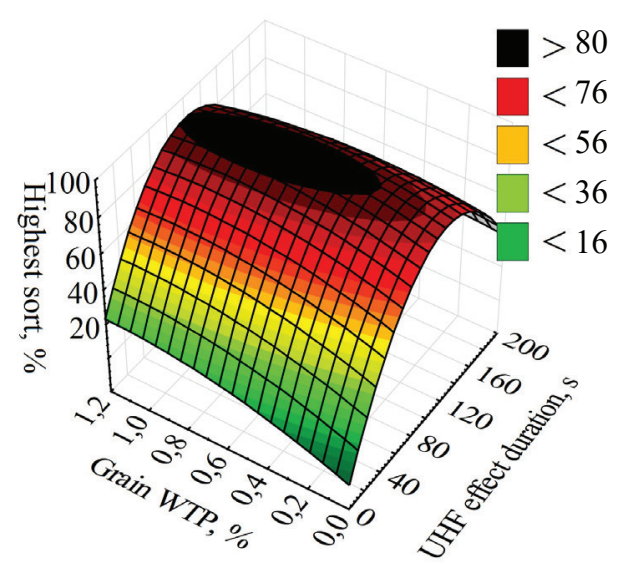

$a$

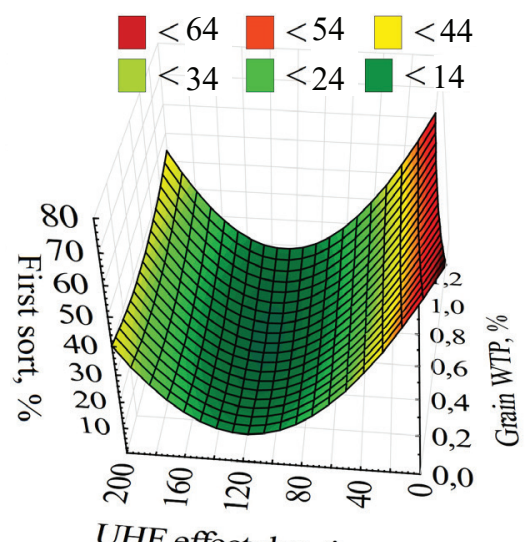

UHF effect duration, s

$b$
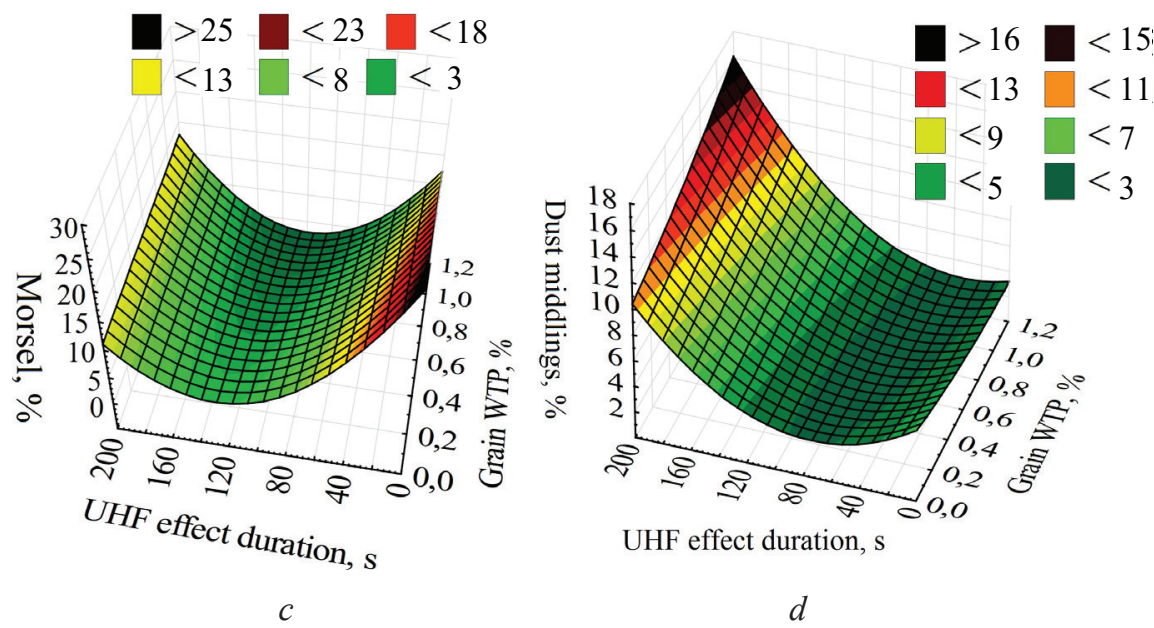

Fig. 4. Influence of humidification and irradiation duration of wheat spelt grains on technical parameters of groats production: $a$ - output of highest sort groats; $b$ - output of first sort groats; $c$ - output of morsel groats; $d$ - output of dust middlings

The methods of dispersion analysis proved the reliable connection between the highest sort rolled groats' total output and water-thermal processing parameters (Fig. 5).

Grain humidification is of the stage character. Moisture penetration in a grain depends on many factors, especially water and external environment temperature, humidification time and gradient. At the same time surface layers of a grain (capsules and aleurone layers) add the course of the humidification process by their influence.

The total output of groats didn't essentially change at different humidification gradients. At different irradiation durations in an UHF-oven this index varied from 90.8 to $97.4 \%$. The output of 
the highest sort groats essentially differed at humidification. Its mean value increased comparing with dry grains by $14 \%$ at humidification gradient $0.5 \%$. At humidification gradient $1.0 \%$ its output increased by 0.8 points. Irradiation time in a microwave oven had more influence on the output of the highest sort groats. At the duration from 20 to $100 \mathrm{~s}$ the output of such goats grew from $32.7 \%$ to $86.6 \%$. The irradiation term prolongation (up to $180 \mathrm{~s}$ ) conditioned the output decrease in 1.4 times.

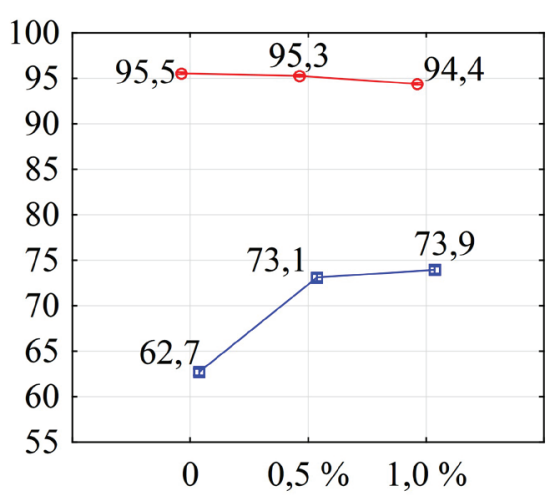

$a$

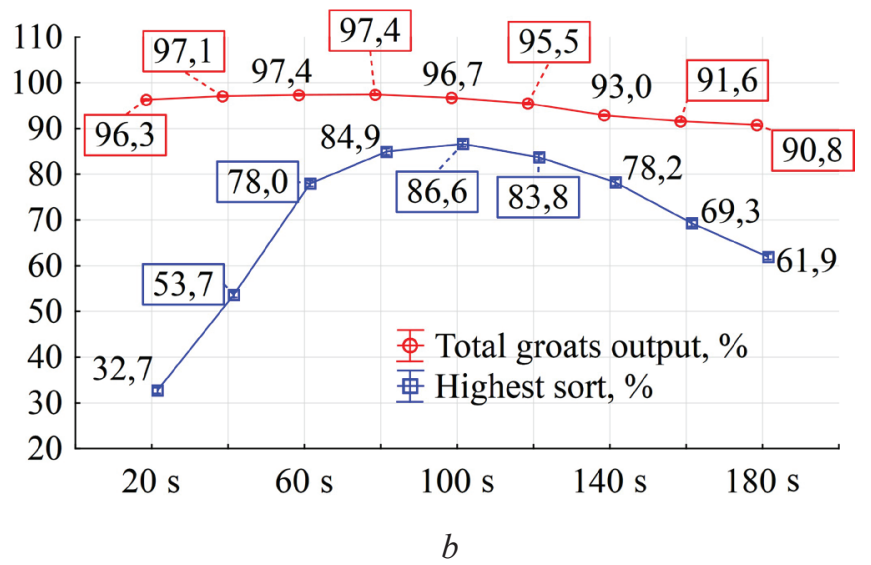

Fig. 5. Influence of UHF-irradiation and humidification of grains on the total output of groats and ones of the highest sort: $a$-humidification influence, $\% ; b$-UHF-irradiation duration influence, $\mathrm{s}$

The most influence on the groats' output was conditioned by the grain irradiation duration in a UHF-oven (Fig. 6). The humidification influence level varied depending on a considered product. In the context of highest sort groats output, grain humidification has the essential influence. It was of the middle force for the total groats output.

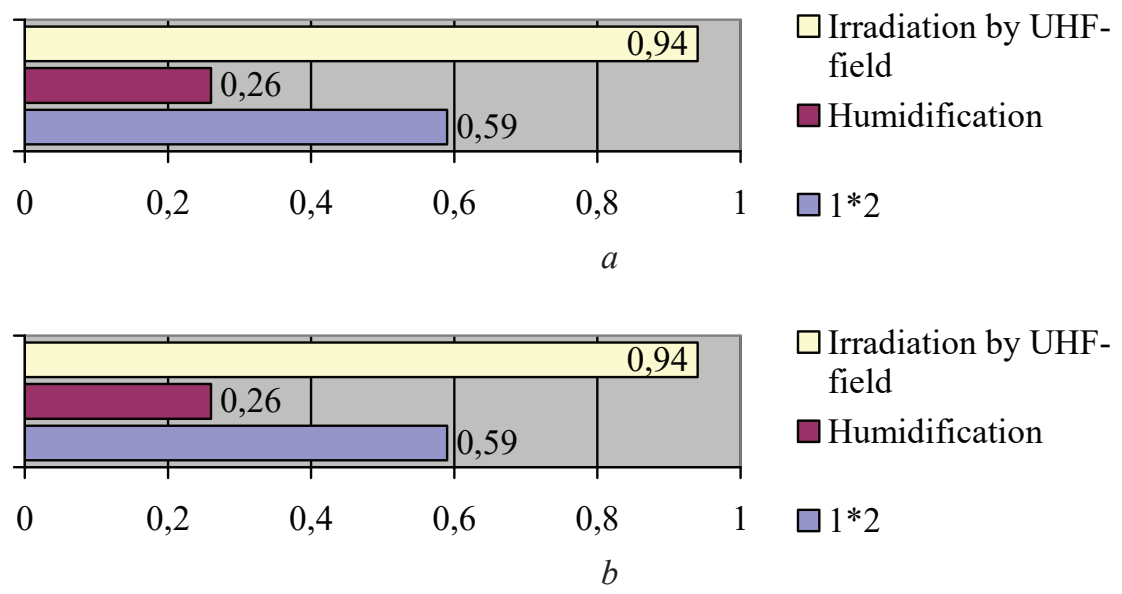

Fig. 6. Influence degree of parameters of grain water-thermal processing on the groats output: $a-$ on the highest sort groats output; $b$ - on the total groats output

It's known, that a change of the content of grain capsules and variety peculiarities essentially influence the culinary quality [14-16]. Humidification and steaming don't essentially influence it (Fig. 7). As far as uniform wheat spelt grains are used (without peeling, of one sort), the total culinary quality of porridge of highest sort rolled groats was equal in all variants. The consistence of grains at chewing was a bit hard, and a porridge smell was weakly expressed. It is expected, because grains were used without peeling. Despite it, the total culinary quality of the porridge was at the high level (7.3-7.4 ponits). 

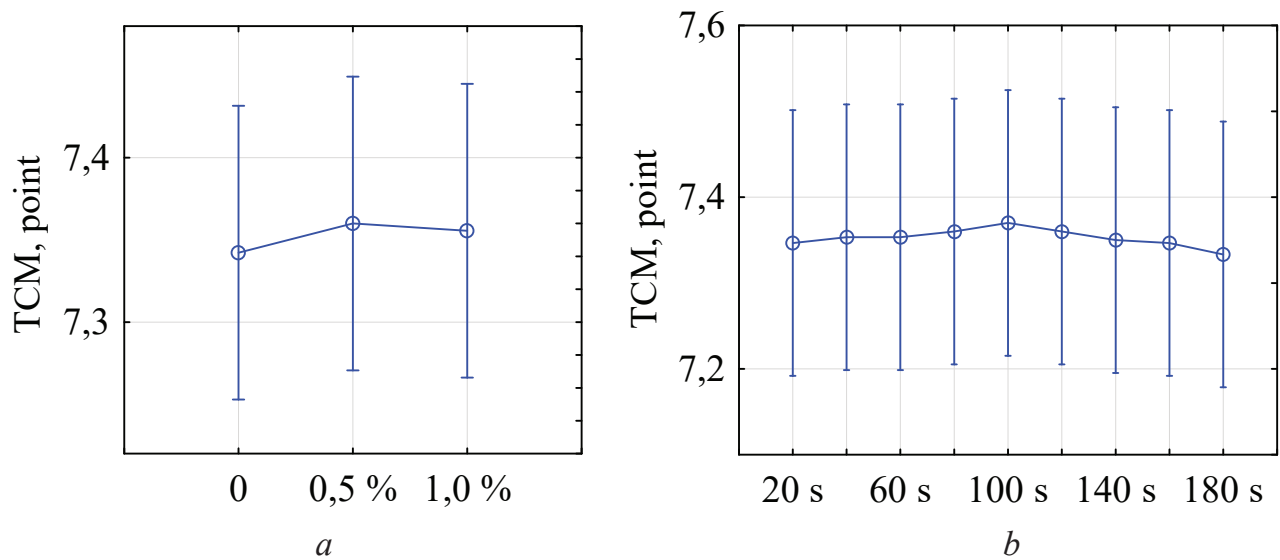

Fig. 7. Influence of grain humidification and its irradiation in a microwave oven on the total culinary mark of the groats (TCM): $a$ - humidification influence; $b$ - UHF-irradiation

Water-thermal processing of grains had the essential influence on the boiling duration of highest sort groats (Fig. 8, a). Thus, the use of humidification by $1 \%$ conditioned the boiling term decrease by $7 \%$ comparing with dry grains. Grains irradiation in a microwave oven had more influence on the boiling term (Fig. 8, b). In $20 \mathrm{~s}$ of UHF-irradiation, the boiling duration was $19.1 \mathrm{~min}$. The processing duration increase up to $180 \mathrm{~s}$ decreased the boiling time to $15.9 \mathrm{~min}$ or by $17 \%$.
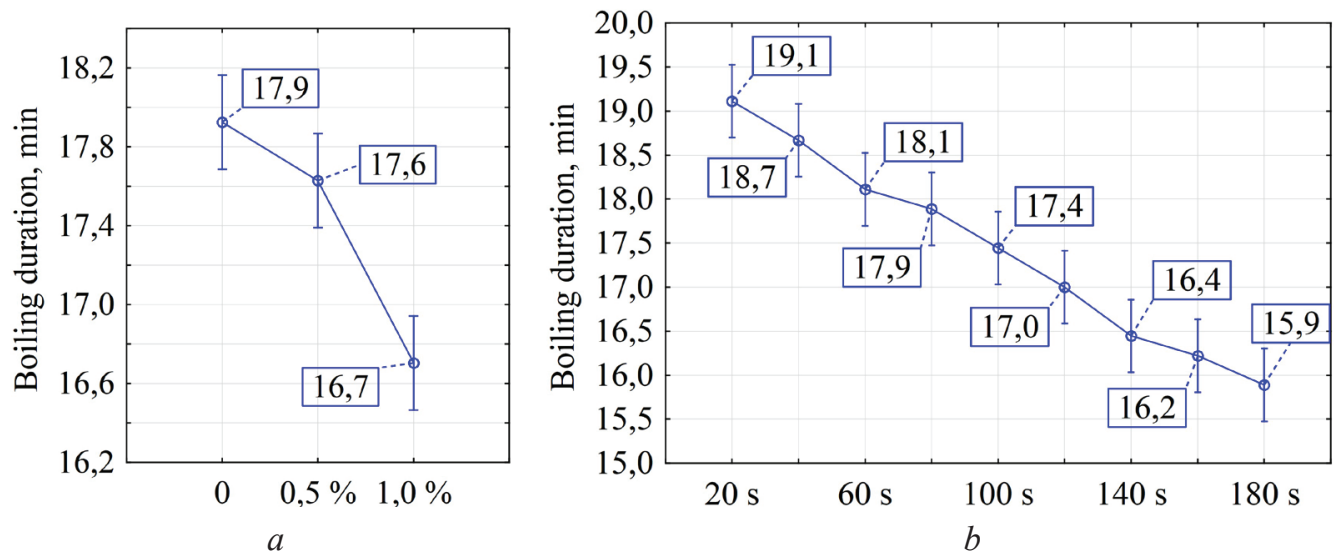

Fig. 8. Influence of grain humidification and its irradiation in a microwave oven on the boiling term of highest sort groats: $a$ - humidification influence; $b$-UHF-irradiation influence

As far as the porridge culinary quality in our research didn't change at different regimes of water-thermal processing, it would be expedient to select production regimes, providing the most output of highest sort groats. Wheat spelt grains humidification by $0.5 \%$ before processing in an UHF-oven has a positive effect. The optimal term of grains irradiation is within 100-120 s. At such processing duration the output of rolled groats of the highest sort was $89.2 \pm 0.8 \%$.

\section{Discussion of results}

The essential importance for a final consumer of groats products is inherent to their culinary quality and cooking terms. Rolled groats of wheat spelt grains, obtained using UHF-irradiation, are similar to ones, produced of analogous cereal crops by culinary quality parameters, studied in works $[15,16]$. The high level of culinary quality of wheat spelt groats is a result of structural differences of the construction of surface layers and their total quantity. The influence of UHF-irradiation on changes in the structure of capsules is little probable. But the use of long- 
term UHF-irradiation essentially lowered the boiling duration as a result of high levels of proteins denaturation and starch pastification.

The offered optimal processing regimes of wheat spelt grains LP1152 (obtained by hybridization of Triticum dicoccum L./Triticum durum Dest.) allow to get up to $30 \%$ more output of the groats of the high culinary quality comparing with traditional processing technologies of soft wheat. Integration of UHF-irradiation in the production technology of rolled groats allows to effectively intensify the process at the expanse of exclusion of the stage of grains humidification before its rolling. The modernized technology is urgent for designed enterprises of low industry because it essentially decreases costs for main funds.

The obtained results are limited by variety properties of the studied raw material. There is a probability that new forms of an increased biological value will be obtained at further selection work. The essential influence on the culinary quality is conditioned by the quantity and mechanical properties of cellulose. That is why a decrease or increase of the number of surface layers of wheat spelt grains will condition a culinary quality change of ready products.

A shortcoming of the conducted study is the use of the apparatus of periodic effect for generating UHF-irradiation that make its real use under production conditions impossible. But the revealed positive influence of UHF-irradiation on the quality and output of groats motivates the development of a laboratory set of constant effect for studying not only irradiation duration, but also other physical parameters.

The great importance for forming the culinary quality of the ready product and its biological value is inherent to variety features of processed grains. Further selection work for decreasing the number of surface layers, protein content increase and increase of its balance level by the amino acid composition is a promising development direction of the studies, presented in the paper. Together with it, a complex analysis of technological properties of new sorts and hybrids of wheat spelt and their change as a result of UHF-irradiation is promising. The obtained results will be necessary for further generalization and widening of recommendations as to optimal regimes for wheat spelt grains processing in groats products.

\section{Conclusions}

It has been established, that it is optimal to humidify grains by $0.5 \%$ with irradiation duration 100-120 s. The use of such processing parameters provides the output of highest sort rolled groats at level $89.2 \pm 0.8 \%$. The culinary quality at that is at the high level (7.4 points). Quality parameters of groats correspond to requirements of SSU «Fast-boiled groats. Technical conditions».

The influence of humidification and irradiation duration in a microwave oven on the output and quality of rolled groats has been revealed. Humidification doesn't essentially influence the total output of groats. The increase of UHF-irradiation duration ( $>120-140 \mathrm{~s})$ conditions the essential growth of the dust middlings output.

The grain irradiation duration in a microwave oven has more influence on the output of highest sort rolled groats comparing with humidification. The influence of humidification is reliably essential. Grain humidification (by $0.5 \%$ ) of wheat spelt of line LP1152 increases the output of highest sort rolled groats by $5 \%$.

The parameters of water-thermal processing of grains have no influence on the culinary quality of the ready product. The boiling term of highest sort groats decreases depending on processing regimes of grains in a microwave oven. After $20 \mathrm{~s}$ of UHF-irradiation, the boiling duration was $19.1 \mathrm{~min}$, after the long-term one (180 s) it decreased by $17 \%$.

\section{References}

[1] Caballerol, Martín, L. M., Alvarez, J. B. (2012). Collection and characterisation of populations of spelt and emmer in Asturias (Spain). Czech Journal of Genetics and Plant Breeding, 41, 175-178. doi: https://oi.org/10.17221/6162-cjgpb

[2] Konvalina, P., Capouchová, I., Stehno, Z., Moudrý, J. (2010). Agronomic characteristics of the spring forms of the wheat landraces (einkorn, emmer, spelt, intermediate bread wheat) grown in organic farming. Journal of Agrobiology, 27 (1), 9-17. doi: https://doi.org/10.2478/s10146-009-0002-3 
[3] Laghetti, G., Fiorentino, G., Hammer, K., Pignone, D. (2009). On the trail of the last autochthonous Italian einkorn (Triticum monococcum L.) and emmer (Triticum dicoccon Schrank) populations: a mission impossible? Genetic Resources and Crop Evolution, 56 (8), 1163-1170. doi: https://doi.org/10.1007/s10722-009-9439-x

[4] Lacko-Bartošová, M., Čurná, V., Lacko-Bartošová, L. (2015). Emmer - ancient wheat suitable for ecological farming. Research Journal of Agricultural Science, 47 (1), 3-10.

[5] Stehno, Z., Paulíčková, I., Bradová, J., Konvalina, P., Capouchová, I., Mašková, E. et. al. (2011). Evaluation of emmer wheat genetic resources aimed at dietary food production. Journal of Life Sciences, 5, 207-212.

[6] Chugunova, O. V., Kryukova, E. V. (2015). Agronomic properties of spelt as unconventional raw materials for production of flour confectionery products. Science Bulletin, 5 (3), 90-100. doi: https://doi.org/10.17117/nv.2015.03.090

[7] Čurná, V., Lacko-Bartošová, M. (2017). Chemical Composition and Nutritional Value of Emmer Wheat (Triticum dicoccon Schrank): a Review. Journal of Central European Agriculture, 18 (1), 117-134. doi: https://doi.org/10.5513/jcea01/18.1.1871

[8] Mitrofanova, O. P., Khakimova, A. G. (2016). New genetic resources in wheat breeding for an increased grain protein content. Vavilov Journal of Genetics and Breeding, 20 (4), 545-554. doi: https://doi.org/10.18699/vj16.177

[9] Desheva, G. N., Kyosev, B. N., Stoyanova, S. D., Sabeva, M. D. (2016). Grain quality of emmer germplasm (Triticum dicoccon) from the National Collection of Bulgaria. Phytologia balcanica, 22 (2), 223-232.

[10] Lacko-Bartošová, M., Čurná, V. (2015). Nutritional characteristics of emmer wheat varieties. Journal of Microbiology, Biotechnology and Food Sciences, 4, 95-98. doi: https://doi.org/10.15414/jmbfs.2015.4.special3.95-98

[11] Ruzhitska, O. M., Borysova, O. V. (2018). Seed productivity and biochemical composition of spelt winter wheat and emmer wheat under south steppe zone conditions. Fiziologiya rasteniy i genetika, 50 (2), 161-169. doi: https://doi.org/10.15407/ frg2018.02.161

[12] Shewry, P. R., Hey, S. J. (2015). The contribution of wheat to human diet and health. Food and Energy Security, 4 (3), $178-202$. doi: https://doi.org/10.1002/fes3.64

[13] Vecherska, L. A., Relina, L. I., Golik, O. V. (2018). Emmer: benefits, drawbacks and prospects. Bulletin of Uman National University of Horticulture, 2, 10-16. doi: https://oi.org/10.31395/2310-0478-2018-21-10-16

[14] Liubych, V., Novikov, V., Polianetska, I., Usyk, S., Petrenko, V., Khomenko, S. et. al. (2019). Improvement of the process of hydrothermal treatment and peeling of spelt wheat grain during cereal production. Eastern-European Journal of Enterprise Technologies, 3 (11 (99)), 40-51. doi: https://doi.org/10.15587/1729-4061.2019.170297

[15] Troccoli, A., Codianni, P. (2005). Appropriate seeding rate for einkorn, emmer, and spelt grown under rainfed condition in southern Italy. European Journal of Agronomy, 22 (3), 293-300. doi: https://oi.org/10.1016/j.eja.2004.04.003

[16] Liubych, V., Voziian, V. (2016). The influence of origin on spelt wheat grains properties. Episteme czasopismo naukowo-kulturalne, II (30), 111-122.

[17] Escarnot, E., Jacquemin, J. M., Agneessens, R. et. al. (2012). Comparative study of the content and profiles of macronutrients in spelt and wheat, a review. Biotechnology, Agronomy, Society and Environment, 16 (2), 243-256.

[18] Wiwart, M., Bytner, M., Graban, Ł., Lajszner, W., Suchowilska, E. (2017). Spelt (Triticum spelta) and Emmer (T. dicoccon) Chaff Used as a Renewable Source of Energy. BioResources, 12 (2). doi: https://doi.org/10.15376/biores.12.2.3744-3750

[19] Osokina, N. M., Liubych, V. V., Novikov, V. V., Leshchenko, I. A. (2020). Yield of spelt wheat rolled grits depending on exposure time to microwave EMF (electromagnetic field of high-frequency current) and water treatment. Collected Works of Uman National University of Horticulture, 1 (96), 52-71. doi: https://doi.org/10.31395/2415-8240-2020-96-1-52-71

[20] Liubych, V., Novikov, V., Zheliezna, V., Prykhodko, V., Petrenko, V., Khomenko, S. et. al. (2020). Improving the process of hydrothermal treatment and dehulling of different triticale grain fractions in the production of groats. Eastern-European Journal of Enterprise Technologies, 3 (11 (105)), 55-65. doi: https://doi.org/10.15587/1729-4061.2020.203737

[21] Neill, G., Al-Muhtaseb, A. H., Magee, T. R. A. (2012). Optimisation of time/temperature treatment, for heat treated soft wheat flour. Journal of Food Engineering, 113 (3), 422-426. doi: https://doi.org/10.1016/j.jfoodeng.2012.06.019

[22] Lamacchia, C., Landriscina, L., D’Agnello, P. (2016). Changes in wheat kernel proteins induced by microwave treatment. Food Chemistry, 197, 634-640. doi: https://doi.org/10.1016/j.foodchem.2015.11.016

[23] Qu, C., Wang, H., Liu, S., Wang, F., Liu, C. (2017). Effects of microwave heating of wheat on its functional properties and accelerated storage. Journal of Food Science and Technology, 54 (11), 3699-3706. doi: https://doi.org/10.1007/s13197-017-2834-y

[24] Kroshko, H. D., Levchenko, V. I., Nazarenko, L. N. et. al. (1998). Pravyla orhanizatsiyi i vedennia tekhnolohichnoho protsesu na krupianykh zavodakh. Kyiv: Viola, 163. 